\title{
Hemşirelikte Kuram ve Modele Dayalı Lisansüstü Tez Çalışmalarının İncelenmesi*
}

\author{
Sevda TÜREN**, Rahime ATAKOĞLU ${ }^{* * *}$, Meral MADENOĞLU KIVANÇ ${ }^{* * * *}$, \\ Asiye GÜL $L^{* * * * *}$
}

Öz

\begin{abstract}
Amaç: Hemşirelik kuram ve modellerine dayalı tasarlanan araştırmalar, hemşirelik bilgi birikimine katkı sağlamakla birlikte hemşirelik uygulamalarını da geliştirir. Bu çalışmanın amacı, ülkemizde hemşirelik alanında kuram ve modele dayalı yapılan lisansüstü tez çalışmalarının nitelik ve niceliğinin incelenmesidir.
\end{abstract}

Yöntem: Çalışmanın örneklemini 2009-2019 yllları arasında Yüksek Öğretim Kurumu (YÖK) veri tabanına yüklenmiş, online tam metnine ulaşılabilen, hemşirelik kuram ve modellerine dayalı tasarlanmış 43 lisansüstü tez (11 yüksek lisans, 32 doktora) çalışması oluşturmuştur. Değerlendirme Fawcett ve Gigliotti’nin kuram/model kullanımında tanımladıkları basamaklar göz önünde bulundurularak yapılmıştır. Bu çalışmaya dâhil edilen tüm araştırmaların etik kurul onayının alınmış olmasına dikkat edilmiştir.

\footnotetext{
Özgün Araştırma Makalesi (Original Research Article)

Geliş / Received: 16.05.2020 \& Kabul / Accepted: 07.08.2020

DOI: https://doi.org/10.38079/igusabder.738.376

${ }^{*}$ Bu çalışma, 24-26 Ekim 2019 tarihinde Erzurum'da düzenlenen Palandöken 2. Uluslararası Hemşirelik Eğitimi Kongresi’nde sözlü bildiri olarak sunulmuştur.

${ }^{* *}$ Dr. Öğr. Üyesi, İstanbul Kültür Üniversitesi, Sağlık Bilimleri Fakültesi, Hemşirelik Bölümü, İstanbul, Türkiye, E-posta: sevdamercanhm@hotmail.com ORCID https://orcid.org/oooo0003-1123-5879

${ }^{* * *}$ Ar. Gör., Uzm. Hemşire, İstanbul Kültür Üniversitesi, Sağllk Bilimleri Fakültesi, Hemşirelik Bölümü, İstanbul, Türkiye, E-posta: r.atakoglu@iku.edu.tr ORCID https://orcid.org/oooo0002-5157-1810

${ }^{* * * *}$ Dr. Öğr. Üyesi, İstanbul Kültür Üniversitesi, Sağlık Bilimleri Fakültesi, Hemşirelik Bölümü, İstanbul, Türkiye, E-posta: mmkvanc@yahoo.com ORCIID https://orcid.org/o000-0001-57872764

${ }^{* * * * *}$ Doç. Dr., İstanbul Kültür Üniversitesi, Sağlık Bilimleri Fakültesi, Hemşirelik Bölümü, İstanbul, Türkiye, E-posta: a.gul@iku.edu.tr ORCID https://orcid.org/o000-0002-4440-5769
} 
Bulgular: Çalışmaların çoğunlukla $(\% 74,4)$ doktora tez çalışmalarından oluştuğu ve kullanılan modellerin başında sağlık inanç modeli $(\% 25,0)$ ve adaptasyon modelinin $(\% 22,5)$ yer aldığı belirlenmiştir. Çalışmaların sıklıkla Halk Sağlığı Hemşireliği $(\% 27,9)$ alanında yapıldığı görülmüştür. Doktora çalışmalarının \%62,5’inde (n=20) kullanılan kuram veya modelin kavram, kuram ve deneysel yapısının belirtilmediği saptanırken; yüksek lisans çalışmalarında bu oran \%63,6 ( $n=7)$ olarak belirlenmiştir. Altı çalışmada (\%14) aynı kuram veya model kullanılarak yapılmış benzer çalışmaların sonuçlarına yer verilmediği, sadece iki doktora çalışmasında $(\% 4,7)$ kullanılan kuram veya modelin zayıf yönleri ve uygulamasında yaşanan zorlukların açıklandığı saptanmıştır.

Sonuç: İncelenen çalışmalarda, hemşirelik araştırmalarında kural ve model kullanımının sınırlı olduğu, kuram ve model kullanımı basamakları doğrultusunda bir standardizasyonun olmadığı belirlenmiştir.

Anahtar Kelimeler: Hemşirelik, model, teori.

\title{
Exploration of the Graduate Thesis Studies Based on Theory and Model in Nursing
}

\begin{abstract}
Aim: Researches designed based on nursing theories and models make a great deal contribution to the accumulation of nursing knowledge alongside improvement in nursing practices. This study aims to analyse the quality and quantity of graduate dissertation studies based on theory and model in the field of nursing in our country.

Method: The sample of the study consisted of 43 graduate theses (11 master's, 32 doctorates) studies designed based on nursing theories and models, which were uploaded to the Higher Education Council database between the years of 2009 and 2019, and which were accessible to the full text. The assessment was made considering the steps defined by Fawcett and Gigliotti in the use of theory/model. All the researches included in this study had ethics committee approval.

Results: Most of the studies (74.4\%) consisted of doctoral dissertation studies and health belief model (25.0\%) as well as the adaptation model (22.5\%) were the leading models. It has been seen that the studies were frequently done in the field of Public Health Nursing (27.9\%). While 62.5\% $(n=20)$ of the doctoral studies did not specify the concept, theory and experimental structure of the theory or model used; this rate was $63.6 \%(n=7)$ in graduate studies. It did not include the results of similar six studies (14\%) using the same theory or model, whereas it has been determined that only two doctoral studies (4.7\%) explained the weaknesses and difficulties experienced in the theory or model used.
\end{abstract}


Conclusion: In the studies analysed, it was determined that the use of rules and models in nursing research was limited and there was no standardization in line with the theory and model usage scales.

Keywords: Nursing, model, theory.

\section{Giriş}

Hemşirelik felsefe, kuram ve uygulamaların yanı sıra; araştırma üzerine kurulmuş bir sağlık disiplinidir ${ }^{1}$. Sağlık ve teknoloji alanındaki gelişim ve değişim, sağlık bakım hizmetinin sezgi ve geleneksel yaklaşımlar yerine bilimsel temellere dayandırılması gerekliliğini beraberinde getirmektedir² ${ }^{2}$ Hemşireliğin mesleki gücü; hemşirelik alanına özgü bilgi birikiminin kanıta dayalı hemşirelik uygulamaları ile sentezlenmesi sonucu arttırılabilir ${ }^{1,3,4}$. Hemşirelik sürecinin temeli olan hemşirelik kuram ve modelleri kullanılarak yapılan araştırmalar ise, güçlü bir hemşirelik biliminin vazgeçilmez ön koşuludur5.

Kuramlar, olayları tanımlamak, açıklamak ve/veya kontrol etmek amacıyla kullanırken; modeller ise uygulamayı daha açık ve belirgin hale getirerek daha bilinçli karar vermeyi sağlar ${ }^{1,6}$. Hemşirelik uygulamalarında kullanılan kuram ve modeller bilgi ve uygulamayı sistematize ederek geleneksel uygulamalar ve sağduyu yerine, kaliteli ve standardize edilmiş bakım verilmesini sağlar ${ }^{6-8}$. Ayrıca, hasta bakımında kapsamlı bir değerlendirme yapılmasını sağlayarak hemşirelik bakımında gözden kaçabilecek birçok uygulamanın önüne geçilmesinde hatırlatıcı rolü bulunmaktadır²,4.

Hemşirelik modelleri karmaşık bir olgu ya da durumu temsil etmek veya anlamak için kavramsal bir çerçeve/araçtır. Bakım hizmeti verilen bireyler birbirinden farklı ihtiyaçlara sahip olduğundan, yalnızca bir hemşirelik modeli veya kuramı kullanmak uygun değildir. Örneğin; sağlı̆̆ın fiziksel yönlerine odaklanan bir bakım modeli, zihinsel sağlık sorunları olan bir birey için uygun olmayabilir' ${ }^{9}$ Kuram ve modeller hemşirelere farklı bakış açısı sağlayarak, kritik düşünme sürecine rehberlik eder ${ }^{10,11}$.

Hemşirelik kuram ve modellerine dayalı tasarlanan araştırmalar, hemşirelik bilgi birikimine katkı sağlamakla birlikte hemşirelik uygulamalarını da geliştirir ${ }^{7,12}$. Bu nedenle, kuram ve modellerin araştırmalarda etkili kullanımı önem kazanmaktadır. 
Özellikle son yıllarda hemşirelik kuram ve modelleri kullanılarak yapılan çalışmalarda artış olduğu bildirilmektedir,13. Ancak ülkemizde hemşirelik alanında kuram ve modele dayalı yapılan lisansüstü tez çalışmalarının nitelik ve niceliğini inceleyen çalışma sayısı sınırlıdır. Bu çalışmada, ülkemizde hemşirelik alanında kuram ve modele dayalı yapılan lisansüstü tez çalışmalarının nitelik ve niceliğinin incelenmesi amaçlanmıştır.

Araştırma soruları:

- 2009-2019 yılları arasında hemşirelik alanında kuram ve modele dayalı yapılan lisansüstü tez araştırmalarının sıklığı nedir?

- Yüksek lisans ve doktora düzeyinde kuram ve model kullanım dağılımı nasıldır?

- Hemşirelik ana bilim dallarına göre kuram ve model kullanımı dağılımı nasıldır?

- Fawcett ve Gigliotti’nin kuram ve model kullanım basamaklarına uygun yürütülmüş müdür?

\section{Gereç ve yöntem}

Çalışma tasarımı: Bu çalışma retrospektif olarak tanımlayıcı tipte tasarlanmıştır.

Evren ve örneklem: Yapılan taramada 2009-2019 tarihleri arasında hemşirelik alanında yapılmış ve Yüksek Öğretim Kurumu (YÖK) Ulusal tez merkezi veri tabanına yüklenmiş 5319 lisansüstü tez çalışması saptandı. Tarama "hemşire, kuram, model" anahtar kelimeleri kullanılarak gerçekleştirildi. YÖK Ulusal tez merkezine yüklenen 5319 lisansüstü tez çalışması içerisinden hemşirelik kuram ve model kullanılarak tasarlanan 64 adet (18 yüksek lisans tezi; 36 doktora tezi model ve 10 doktora tezi kuram temelli olarak tasarlanan) tez çalışması belirlendi. Online olarak tam metnine ulaşılamayan araştırmalar ( $n=21)$ çalışma dışı bırakıldı. Sonuç olarak; 43 lisansüstü tez çalışması araştırmanın örneklemini oluşturdu. Çalışma 2 hemşirelik kuramı ve 41 hemşirelik modeli kullanan araştırma ile yapıldı.

Verilerin toplanması ve değerlendirilmesi: Tez çalışmaları Fawcett ve Gigliotti’nin kuram/model kullanımında tanımladıkları basamaklar doğrultusunda değerlendirildi ${ }^{3,8,14}$. Araştırmacılar tarafından oluşturulan form ile tezlerin türü, hangi yılda yapıldığı, hangi hemşirelik kuramı veya modelinden yararlanıldı̆̆ı, örneklem grubu, araştırma tasarımı, hangi hemşirelik ana bilim dalında gerçekleştiği kayıt altına 
alındı. Tezlerin nicelik analizinde Fawcett ve Gigliotti'nin hemşirelik kuram/model kullanımında tanımladıkları basamaklara uygunlukları değerlendirildi. Bu basamaklar şunlardır:

- Kuram/modelin içeriğinin ve araştırmada kullanımının anlaşılması: Bu basamakta kullanılan model veya kuram ile ilgili kavramların açıklanması, birbiri ile olan ilişkilerinin tanımlanması ve kullanılan modele ait kuralların birincil kaynaktan alıntılanması beklenmektedir.

- Kuram/model ile ilgili yapılan araștırma literatürünün analiz edilmesi: Araştırmada aynı kuram/model kullanılarak yapılan çalışmalara yer verilmesinin, tasarımın oluşturulmasında yol gösterici olacağı, farklı hasta gruplarıyla yapılan çalışmalarda nasıl uygulandığı ve kuram/model ile ilgili bilgiyi arttıracă̆ı gibi önemli katkıları olduğu vurgulanmaktadır.

- Kavramsal, kuramsal ve deneysel yapının tanımlanması ve araştırmada kullanılması: Bu basamakta kuram/modelin kavramsal, kuramsal ve deneysel yapısının şematize edilmesi ve birbiri arasındaki ilişkinin tanımlanması beklenmektedir.

- Kuram/modelin uygulanabilirliği ve güvenilirliğinin değerlendirilmesi: Araştırma bulgularını sunmak ve kuram/modelin uygulanabilirliğini tartışmak gerektiği bildirilmektedir. Ayrıca, kullanılan kuram/modelin güçlü ve zayıf yönlerinin belirtilmesinin önemi vurgulanmaktadır.

Çalışma analizi araştırmacıların birbirinden bağımsız olarak tezleri okuması ve verilerin karşılaştırılması şeklinde yapıldı. Elde edilen veriler bilgisayar ortamına aktarıldı. Çalışmaya dahil edilen tüm araştırmaların etik kurul onayının olmasına dikkat edildi.

\section{Bulgular:}

Araştırmaya dahil edilen 43 lisansüstü tez çalışmasının \%74,4'ünün $(n=32)$ doktora, \%25,6'sının ( $\mathrm{n}=11$ ) ise yüksek lisans tezlerinden oluştuğu belirlendi (Tablo 1 ve 2). 
Tablo 1. Hemşirelik modellerine dayalı lisansüstü tez çalışmaları

\begin{tabular}{|c|c|c|c|c|c|}
\hline $\begin{array}{c}\text { Hemşirelik } \\
\text { Modeli }\end{array}$ & Örneklem & $\begin{array}{l}\text { Araştırma } \\
\text { tasarımı }\end{array}$ & Ana Bilim Dalı & $\begin{array}{l}\text { Tez } \\
\text { türüi }\end{array}$ & Y1l \\
\hline $\begin{array}{l}\text { Sağllk İnanç } \\
\text { Modeli }\end{array}$ & $\begin{array}{l}\text { Periferik arter hastalığı tanısı } \\
\text { konulmuş } 30 \text { hasta }\end{array}$ & Kesitsel & $\begin{array}{l}\text { Dahili Hastalıklar } \\
\text { Hemşireliği }\end{array}$ & $\begin{array}{l}\text { Yüksek } \\
\text { Lisans }\end{array}$ & 2010 \\
\hline $\begin{array}{l}\text { Günlük Yaşam } \\
\text { Aktiviteleri } \\
\text { Modeli }\end{array}$ & $\begin{array}{l}100 \text { zihinsel engelli birey } \\
\text { ailesi }\end{array}$ & Yarı deneysel & $\begin{array}{l}\text { Cerrahi } \\
\text { Hastalıklar } \\
\text { Hemşireliği }\end{array}$ & $\begin{array}{l}\text { Yüksek } \\
\text { Lisans }\end{array}$ & 2010 \\
\hline $\begin{array}{l}\text { Sağllk Ínanç } \\
\text { Modeli }\end{array}$ & $\begin{array}{l}\text { Kadınhanı bir nolu ASM } \\
\text { kullanan bireyler ile ilçeye } \\
\text { bağlı yedi köyde yaşayan } \\
\text { toplam } 392 \text { birey }\end{array}$ & Tanımlayıcı & $\begin{array}{l}\text { Halk Sağlığı } \\
\text { Hemşireliği }\end{array}$ & $\begin{array}{l}\text { Yüksek } \\
\text { Lisans }\end{array}$ & 2018 \\
\hline $\begin{array}{l}\text { Sağllk İnanç } \\
\text { Modeli }\end{array}$ & $\begin{array}{l}\text { 18-65 yaş arası ASM } \\
\text { kullanan } 772 \text { birey }\end{array}$ & Tanımlayıcı & $\begin{array}{l}\text { Halk Sağllğı } \\
\text { Hemşireliği }\end{array}$ & $\begin{array}{l}\text { Yüksek } \\
\text { Lisans }\end{array}$ & 2018 \\
\hline $\begin{array}{l}\text { Sağlık İnanç } \\
\text { Modeli }\end{array}$ & $\begin{array}{l}\text { 30 DM tanısı konulmuş } \\
\text { hasta }\end{array}$ & Yarı deneysel & $\begin{array}{l}\text { Hemşirelik } \\
\text { Esasları }\end{array}$ & $\begin{array}{l}\text { Yüksek } \\
\text { Lisans }\end{array}$ & 2018 \\
\hline $\begin{array}{l}\text { Adaptasyon } \\
\text { Modeli }\end{array}$ & $\begin{array}{l}\text { Kalça veya diz artroplasti } \\
\text { ameliyatı olan } 78 \text { hasta }\end{array}$ & $\begin{array}{l}\text { Randomize } \\
\text { kontrollü } \\
\text { deneysel }\end{array}$ & $\begin{array}{l}\text { Cerrahi } \\
\text { Hastalıklar } \\
\text { Hemşireliği }\end{array}$ & $\begin{array}{l}\text { Yüksek } \\
\text { Lisans }\end{array}$ & 2018 \\
\hline Yaşam Modeli & $148 \mathrm{KOAH}$ hastası & $\begin{array}{l}\text { Randomize } \\
\text { kontrollü } \\
\text { yarı deneysel }\end{array}$ & $\begin{array}{l}\text { Dahili Hastalıklar } \\
\text { Hemşireliği }\end{array}$ & $\begin{array}{l}\text { Yüksek } \\
\text { Lisans }\end{array}$ & 2018 \\
\hline $\begin{array}{l}\text { Adaptasyon } \\
\text { Modeli }\end{array}$ & $\begin{array}{l}\text { Bariatrik cerrahi operasyonu } \\
\text { geçirmiş } 46 \text { hasta }\end{array}$ & Deneysel & $\begin{array}{l}\text { Hemşirelik } \\
\text { Esasları }\end{array}$ & $\begin{array}{l}\text { Yüksek } \\
\text { Lisans }\end{array}$ & 2019 \\
\hline $\begin{array}{l}\text { Adaptasyon } \\
\text { Modeli }\end{array}$ & Tip 1 DM tanıll 110 ergen & $\begin{array}{l}\text { Randomize } \\
\text { kontrollü } \\
\text { yarı deneysel }\end{array}$ & $\begin{array}{l}\text { Çocuk Sağlı̆̆ı ve } \\
\text { Hastalıkları } \\
\text { Hemşireliği }\end{array}$ & $\begin{array}{l}\text { Yüksek } \\
\text { Lisans }\end{array}$ & 2019 \\
\hline $\begin{array}{l}\text { Bilgi, } \\
\text { Motivasyon, } \\
\text { Davranış } \\
\text { Becerileri Modeli }\end{array}$ & $\begin{array}{l}\text { 1.aşamada } 229 \text { emziren } \\
\text { anne;2.aşamada ilk aşama } \\
\text { içerisinden ilk } 50 \text { emziren } \\
\text { anne }\end{array}$ & $\begin{array}{l}\text { Kesitsel-Yarı } \\
\text { Deneysel }\end{array}$ & $\begin{array}{l}\text { Doğum ve Kadın } \\
\text { Hastalıkları } \\
\text { Hemşireliği }\end{array}$ & $\begin{array}{l}\text { Yüksek } \\
\text { Lisans }\end{array}$ & 2019 \\
\hline $\begin{array}{l}\text { Sağllğı } \\
\text { Geliştirme } \\
\text { Modeli }\end{array}$ & $\begin{array}{l}\text { Kardiyopulmoner } \\
\text { rehabilitasyon programına } \\
\text { katılan } 56 \text { hasta }\end{array}$ & Deneysel & $\begin{array}{l}\text { Hemşirelik } \\
\text { Esasları }\end{array}$ & $\begin{array}{l}\text { Yüksek } \\
\text { Lisans }\end{array}$ & 2019 \\
\hline $\begin{array}{l}\text { Sağlık İnanç } \\
\text { Modeli }\end{array}$ & $\begin{array}{l}\text { Obezite polikliniğine } \\
\text { başvuran } 400 \text { yetişkin birey }\end{array}$ & Kesitsel & $\begin{array}{l}\text { Dahili Hastalıklar } \\
\text { Hemşireliği }\end{array}$ & Doktora & 2010 \\
\hline $\begin{array}{l}\text { Sağlığı } \\
\text { Geliştirme } \\
\text { Modeli }\end{array}$ & $\begin{array}{l}\text { 1.Aşama: } 40 \text { meme kanseri, } \\
\text { 27 serviks kanseri kadın } \\
\text { 2.Aşama: } 100 \text { yoksul kadın }\end{array}$ & Yarı deneysel & $\begin{array}{l}\text { Halk Sağlığı } \\
\text { Hemşireliği }\end{array}$ & Doktora & 2011 \\
\hline Sistemler Modeli & $\begin{array}{l}\text { 30 yaşlı bireyin birincil } \\
\text { bakım verenleri }\end{array}$ & Yarı deneysel & $\begin{array}{l}\text { Halk Sağlı̆̆ı } \\
\text { Hemșireliği }\end{array}$ & Doktora & 2012 \\
\hline
\end{tabular}




\begin{tabular}{|c|c|c|c|c|c|}
\hline $\begin{array}{l}\text { Sağlığ } \\
\text { Geliştirme } \\
\text { Modeli }\end{array}$ & $\begin{array}{l}\text { 1.Aşama: } 39 \text { kadın } \\
\text { 2.Aşama: } 200 \text { kadın }\end{array}$ & Yarı deneysel & $\begin{array}{l}\text { Halk Sağlığ } \\
\text { Hemşireliği }\end{array}$ & Doktora & 2013 \\
\hline $\begin{array}{l}\text { Transteoretik } \\
\text { Model }\end{array}$ & Tip 2 DM'li 50 hasta & $\begin{array}{l}\text { Randomize } \\
\text { kontrollü } \\
\text { deneysel }\end{array}$ & $\begin{array}{l}\text { Halk Sağlığı } \\
\text { Hemşireliği }\end{array}$ & Doktora & 2015 \\
\hline $\begin{array}{l}\text { Davranışsal } \\
\text { Sistem Modeli }\end{array}$ & $\begin{array}{l}\text { 7. sınıfa devam eden } 83 \\
\text { öğrenci }\end{array}$ & $\begin{array}{l}\text { Randomize } \\
\text { kontrollü } \\
\text { deneysel }\end{array}$ & $\begin{array}{l}\text { Çocuk Sağlığı ve } \\
\text { Hastalıkları Hem. }\end{array}$ & Doktora & 2015 \\
\hline $\begin{array}{l}\text { Transteoretik } \\
\text { Model }\end{array}$ & $\begin{array}{l}\text { Ağızotu (dumansız tütün) } \\
\text { kullanan 9o lise öğrencisi }\end{array}$ & Yarı deneysel & $\begin{array}{l}\text { Halk Sağlığı } \\
\text { Hemşireliği }\end{array}$ & Doktora & 2015 \\
\hline $\begin{array}{l}\text { Adaptasyon } \\
\text { Modeli }\end{array}$ & $\begin{array}{l}\text { Demans tanısı konulmuş } 60 \\
\text { poliklinik hastası }\end{array}$ & $\begin{array}{l}\text { Randomize } \\
\text { kontrollü } \\
\text { deneysel }\end{array}$ & $\begin{array}{l}\text { Psikiyatri } \\
\text { Hemşireliği. }\end{array}$ & Doktora & 2016 \\
\hline Sistemler Modeli & $\begin{array}{l}\text { Depresyon tanısı konulmuş } \\
43 \text { hasta }\end{array}$ & $\begin{array}{l}\text { Randomize } \\
\text { kontrollü } \\
\text { deneysel }\end{array}$ & $\begin{array}{l}\text { Psikiyatri } \\
\text { Hemşireliği }\end{array}$ & Doktora & 2016 \\
\hline $\begin{array}{l}\text { İnsan Bakım } \\
\text { Modeli }\end{array}$ & Tip 1 DM'li 34 adölesan & $\begin{array}{l}\text { Randomize } \\
\text { kontrollü } \\
\text { deneysel }\end{array}$ & $\begin{array}{l}\text { Çocuk Sağlığı ve } \\
\text { Hastalıkları Hem. }\end{array}$ & Doktora & 2016 \\
\hline $\begin{array}{l}\text { İnsan Bakım } \\
\text { Modeli }\end{array}$ & 158 yetişkin onkoloji hastası & $\begin{array}{l}\text { Randomize } \\
\text { kontrollü } \\
\text { deneysel }\end{array}$ & $\begin{array}{l}\text { Halk Sağlığ } \\
\text { Hemşireliği }\end{array}$ & Doktora & 2016 \\
\hline $\begin{array}{l}\text { Transteoretik } \\
\text { Model }\end{array}$ & $\begin{array}{l}\text { 3-6 yaş çocuğu olan } 65 \\
\text { ebeveyn }\end{array}$ & Yarı deneysel & $\begin{array}{l}\text { Halk Sağlığı } \\
\text { Hemşireliği }\end{array}$ & Doktora & 2017 \\
\hline $\begin{array}{l}\text { Adaptasyon } \\
\text { Modeli }\end{array}$ & $\begin{array}{l}81 \text { yetişkin hemodiyaliz } \\
\text { hastası }\end{array}$ & Yarı deneysel & $\begin{array}{l}\text { Dahili Hastalıklar } \\
\text { Hemşireliği }\end{array}$ & Doktora & 2017 \\
\hline $\begin{array}{l}\text { Fonksiyonel } \\
\text { Sağlık Örüntüleri } \\
\text { Modeli }\end{array}$ & 120 kalp yetersizliği hastası & $\begin{array}{l}\text { Randomize } \\
\text { kontrollü } \\
\text { deneysel }\end{array}$ & $\begin{array}{l}\text { Dahili Hastalıklar } \\
\text { Hemşireliği }\end{array}$ & Doktora & 2017 \\
\hline $\begin{array}{l}\text { Sağll̆̆ } \\
\text { Geliş̧tirme } \\
\text { Modeli }\end{array}$ & $\begin{array}{l}\text { 1.Aşama:401 menapozal } \\
\text { kadın 2.Aşama: } 64 \\
\text { menapozal kadın }\end{array}$ & Yarı deneysel & $\begin{array}{l}\text { Doğum ve Kadın } \\
\text { Hastalıkları } \\
\text { Hemşireliği }\end{array}$ & Doktora & 2017 \\
\hline $\begin{array}{l}\text { İnsan Bakım } \\
\text { Modeli }\end{array}$ & Tip 2 DM'li 132 hasta & Yarı deneysel & $\begin{array}{l}\text { Dahili Hastalıklar } \\
\text { Hemşireliği }\end{array}$ & Doktora & 2017 \\
\hline $\begin{array}{l}\text { Adaptasyon } \\
\text { Modeli }\end{array}$ & $\begin{array}{l}\text { Bariatrik cerrahi geçiren } 32 \\
\text { hasta }\end{array}$ & Yarı deneysel & $\begin{array}{l}\text { Cerrahi } \\
\text { Hastalıklar } \\
\text { Hemşireliği }\end{array}$ & Doktora & 2018 \\
\hline $\begin{array}{l}\text { Adaptasyon } \\
\text { Modeli }\end{array}$ & $\begin{array}{l}\text { Tibbi terminasyon kararı } \\
\text { alınan } 77 \text { gebe kadın }\end{array}$ & $\begin{array}{l}\text { Randomize } \\
\text { kontrollü } \\
\text { deneysel }\end{array}$ & $\begin{array}{l}\text { Doğum ve Kadın } \\
\text { Hastalıkları Hem. }\end{array}$ & Doktora & 2018 \\
\hline
\end{tabular}




\begin{tabular}{|c|c|c|c|c|c|}
\hline $\begin{array}{l}\text { Sağlık İnanç } \\
\text { Modeli }\end{array}$ & $\begin{array}{l}132 \text { yetişkin hemodiyaliz } \\
\text { hastası }\end{array}$ & $\begin{array}{l}\text { Randomize } \\
\text { kontrollü } \\
\text { deneysel }\end{array}$ & $\begin{array}{l}\text { Cerrahi } \\
\text { Hastalıklar } \\
\text { Hemşireliği }\end{array}$ & Doktora & 2018 \\
\hline Learn Modeli & $\begin{array}{l}\text { Meme kanseri tanısı } \\
\text { konulmuş } 73 \text { hasta }\end{array}$ & Yarı deneysel & $\begin{array}{l}\text { Cerrahi } \\
\text { Hastalıklar } \\
\text { Hemşireliği }\end{array}$ & Doktora & 2018 \\
\hline $\begin{array}{l}\text { Adaptasyon } \\
\text { Modeli }\end{array}$ & $\begin{array}{l}\text { Miyokard infarktüsü } \\
\text { nedeniyle tedavi gören } 66 \\
\text { hasta }\end{array}$ & $\begin{array}{l}\text { Randomize } \\
\text { kontrollü } \\
\text { deneysel }\end{array}$ & $\begin{array}{l}\text { Dahili Hastalıklar } \\
\text { Hemşireliği }\end{array}$ & Doktora & 2018 \\
\hline $\begin{array}{l}\text { Adaptasyon } \\
\text { Modeli }\end{array}$ & $\begin{array}{l}\text { Multiple Skleroz tanısı } \\
\text { konulmuş } 244 \text { hasta }\end{array}$ & $\begin{array}{l}\text { Randomize } \\
\text { kontrollü } \\
\text { deneysel }\end{array}$ & $\begin{array}{l}\text { Halk Sağlığı } \\
\text { Hemşireliği }\end{array}$ & Doktora & 2018 \\
\hline $\begin{array}{l}\text { Sağlık İnanç } \\
\text { Modeli }\end{array}$ & $\begin{array}{l}\text { 18-65 yaş grubu } 128 \text { obez } \\
\text { hasta }\end{array}$ & Yarı deneysel & $\begin{array}{l}\text { Halk Sağlığı } \\
\text { Hemşireliği }\end{array}$ & Doktora & 2018 \\
\hline $\begin{array}{l}\text { İnsan Bakım } \\
\text { Modeli }\end{array}$ & 64 palyatif bakım hastası & $\begin{array}{l}\text { Randomize } \\
\text { kontrollü } \\
\text { deneysel }\end{array}$ & $\begin{array}{l}\text { Dahili Hastalıklar } \\
\text { Hemşireliği }\end{array}$ & Doktora & 2018 \\
\hline $\begin{array}{l}\text { Sağlık İnanç } \\
\text { Modeli }\end{array}$ & $\begin{array}{l}163 \text { premenstrual sendromlu } \\
\text { kadın }\end{array}$ & $\begin{array}{l}\text { Randomize } \\
\text { kontrollü } \\
\text { deneysel }\end{array}$ & $\begin{array}{l}\text { Doğum ve Kadın } \\
\text { Hastalıkları Hem. }\end{array}$ & Doktora & 2018 \\
\hline $\begin{array}{l}\text { Sağlık İnanç } \\
\text { Modeli }\end{array}$ & $\begin{array}{l}\text { Postmenapoz dönemindeki } \\
82 \text { kadın }\end{array}$ & $\begin{array}{l}\text { Randomize } \\
\text { kontrollü } \\
\text { deneysel }\end{array}$ & $\begin{array}{l}\text { Doğum ve Kadın } \\
\text { Hastalıkları Hem. }\end{array}$ & Doktora & 2018 \\
\hline $\begin{array}{l}\text { Günlük Yaşam } \\
\text { Aktiviteleri } \\
\text { Modeli }\end{array}$ & $\begin{array}{l}\text { Cerrahi operasyon geçiren } \\
\text { meme kanserli hastalar } \\
\text { Aşama: } 142 \text { hasta } \\
\text { Aşama: } 60 \text { hasta }\end{array}$ & $\begin{array}{l}\text { Randomize } \\
\text { kontrollü } \\
\text { deneysel }\end{array}$ & $\begin{array}{l}\text { Cerrahi } \\
\text { Hastalıklar } \\
\text { Hemşireliği }\end{array}$ & Doktora & 2019 \\
\hline $\begin{array}{l}\text { Sağlık İnanç } \\
\text { Modeli }\end{array}$ & HPV DNA (+) 16 kadın & $\begin{array}{l}\text { Fenomenoloj } \\
\text { ik tasarım }\end{array}$ & $\begin{array}{l}\text { Doğum ve Kadın } \\
\text { Hastalıkları Hem. }\end{array}$ & Doktora & 2019 \\
\hline $\begin{array}{l}\text { Sağlı̆̆ } \\
\text { Geliştirme } \\
\text { Modeli }\end{array}$ & $\begin{array}{l}\text { KOAH tanısı konulmuş } 120 \\
\text { hasta }\end{array}$ & $\begin{array}{l}\text { Randomize } \\
\text { kontrollü } \\
\text { deneysel }\end{array}$ & $\begin{array}{l}\text { Dahili Hastalıklar } \\
\text { Hemşireliği }\end{array}$ & Doktora & 2019 \\
\hline $\begin{array}{l}\text { Sağlığı } \\
\text { Geliştirme } \\
\text { Modeli }\end{array}$ & $\begin{array}{l}\text { Menapoz dönemindeki } 156 \\
\text { kadın }\end{array}$ & $\begin{array}{l}\text { Randomize } \\
\text { kontrollü } \\
\text { deneysel }\end{array}$ & $\begin{array}{l}\text { Doğum ve Kadın } \\
\text { Hastalıkları Hem. }\end{array}$ & Doktora & 2019 \\
\hline
\end{tabular}

ASM: Aile Sağlığı Merkezi, DM: Diabetes Mellitus, KOAH: Kronik Obstrüktif Akciğer Hastalı̆̆ı, HPV: Human Papilloma Virüs 
Tablo 2. Hemşirelik kuramlarına dayalı lisansüstü tez çalışmaları

\begin{tabular}{|l|l|l|l|l|c|}
\hline \multicolumn{1}{|c|}{$\begin{array}{c}\text { Hemşirelik } \\
\text { Kuramı }\end{array}$} & \multicolumn{1}{|c|}{ Örneklem } & $\begin{array}{c}\text { Araştırma } \\
\text { tasarımı }\end{array}$ & $\begin{array}{c}\text { Ana Bilim } \\
\text { Dalı }\end{array}$ & $\begin{array}{c}\text { Tez } \\
\text { türü }\end{array}$ & Yıl \\
\hline Konfor Kuramı & 90 primipar kadın & $\begin{array}{l}\text { Randomize } \\
\text { kontrollü } \\
\text { deneysel }\end{array}$ & $\begin{array}{l}\text { Doğum ve } \\
\text { Kadın } \\
\text { Hastalıkları } \\
\text { Hem. }\end{array}$ & Doktora & 2018 \\
\hline $\begin{array}{l}\text { Öz Yeterlilik } \\
\text { Kuramı }\end{array}$ & $\begin{array}{l}\text { Madde kullanım } \\
\text { bozukluğu olan } 112 \\
\text { yetişkin birey }\end{array}$ & $\begin{array}{l}\text { Randomize } \\
\text { kontrollü } \\
\text { deneysel }\end{array}$ & $\begin{array}{l}\text { Halk Sağlı̆̆ } \\
\text { Hemşireliği }\end{array}$ & Doktora & 2019 \\
\end{tabular}

Çalışmaların yıllara göre dağılımı incelendiğinde; son yıllarda hemşirelik kuram ve model kullanımında artış olduğu gözlendi. Değerlendirilen çalışmaların büyük çoğunluğunun (\%37,2; n=16) 2018 yllında gerçekleştirildiği belirlendi (Şekil 1).

Şekil 1. Lisansüstü tez çalışmalarında hemşirelik model ve kuram kullanımının yıllara göre dağılımı

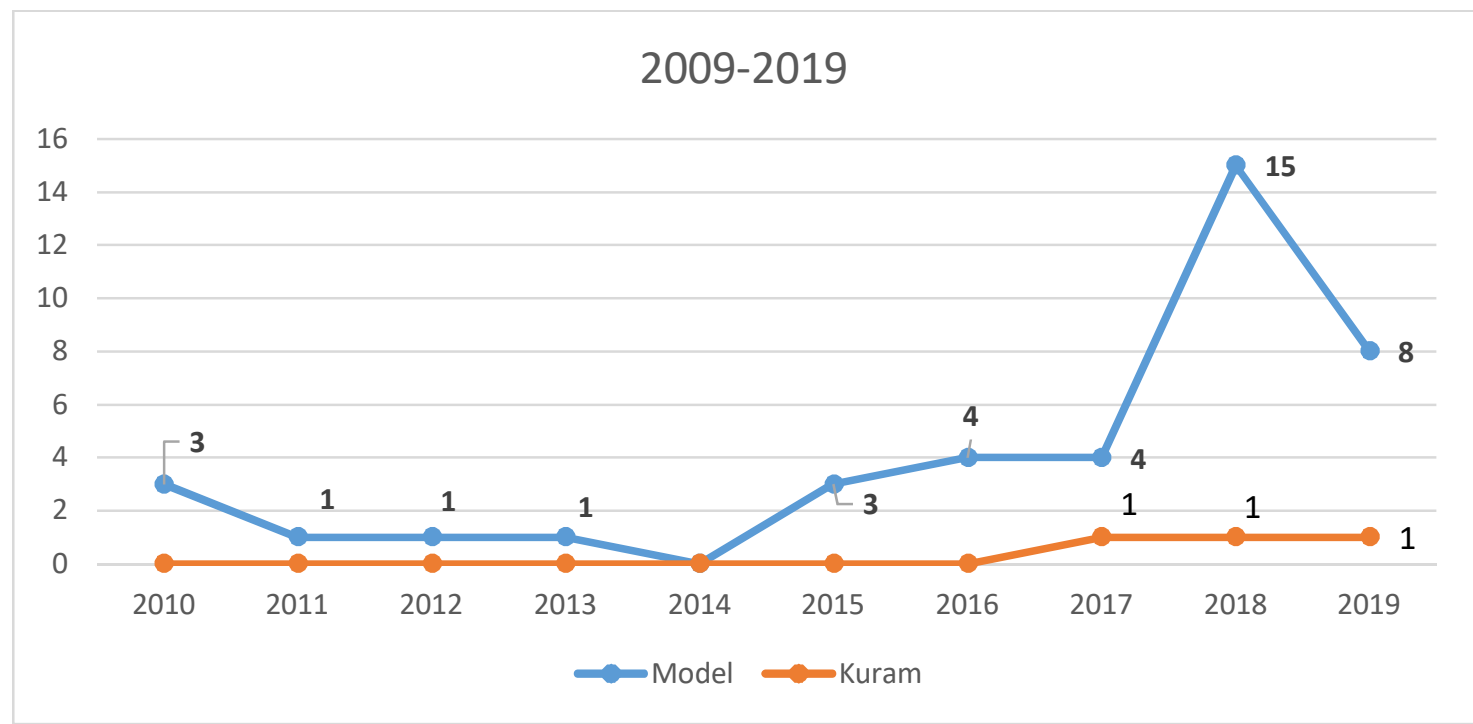

İncelenen çalışmaların \%48,8’inin $(n=21)$ randomize kontrollü olarak tasarlandığı saptandı (Tablo 1). Yapılan çalışmalar hemşirelik ana bilim dallarına göre 
incelendiğinde; ilk sırada Halk Sağlı̆̆ı Hemşireliği $(\% 27,9)$ yer alırken; sıralamayı Dahili Hastalıklar Hemşireliği $(\% 20,9)$ ve Doğum ve Kadın Hastalıkları Hemşireliği $(\% 18,6)$ ana bilim dalının takip ettiği görüldü (Şekil 2).

Şekil 2. Lisansüstü tez çalışmalarının hemşirelik ana bilim dallarına göre dağılımı

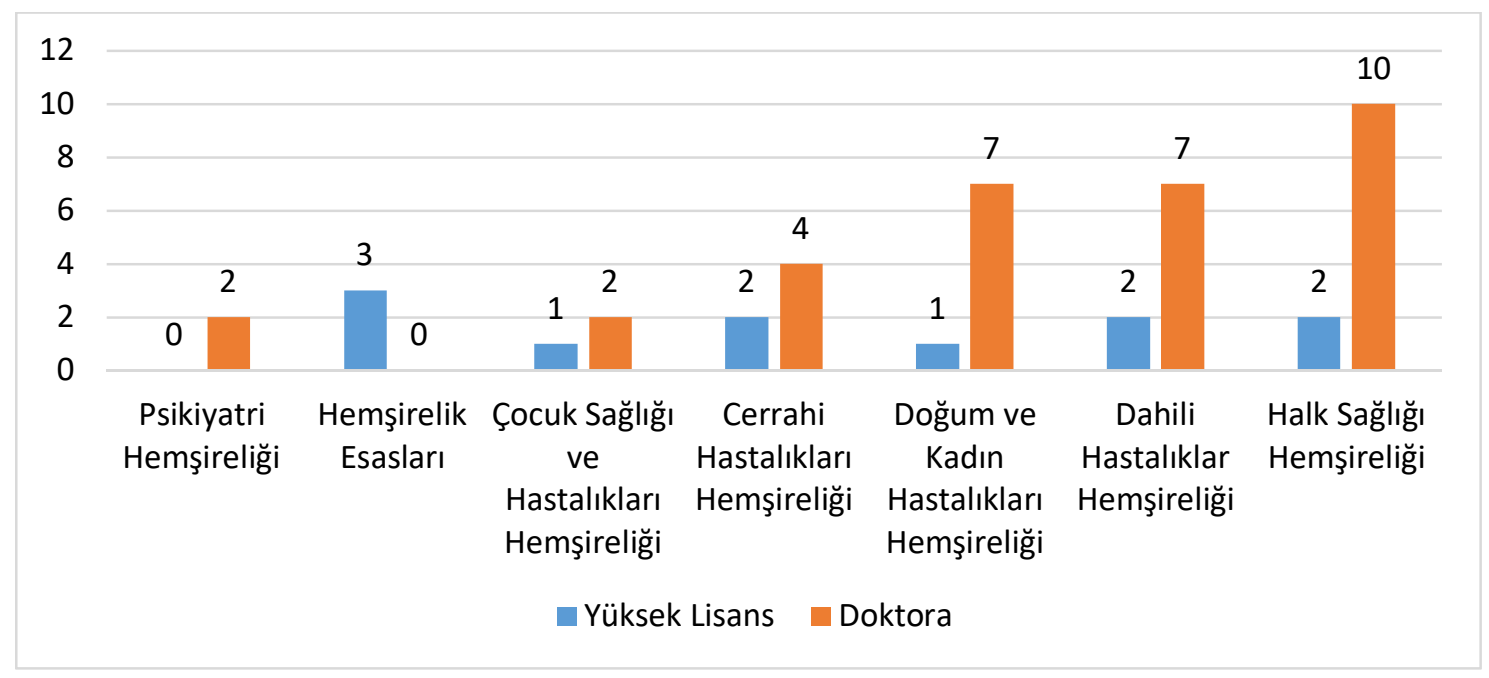

Çalışmaların örneklemleri değerlendirildiğinde, çoğunlukla (\%93) yetişkin bireylerde yapılan çalışmalar olduğu belirlendi. Çalışmada kullanılan hemşirelik kuram ve modelleri incelendiğinde; Sağlık İnanç Modeli (\%25,0) ve Adaptasyon Modeli'nin $(\% 22,5)$ ilk sıralarda yer aldığı saptandı (Tablo 1).

Tezlerin analizinde;

- Kuram/modelin içeriğinin ve araștırmada kullanımının anlașılması: Yapılan inceleme sonucu, çalışmaların çoğunlukla $(\% 90,7)$ bu aşamaya uyum sağladıkları, dört çalışmada $(\% 9,3)$ ise kullanılan kuram veya model ile ilgili birincil kaynağa yer verilmediği görüldü.

- Kuram/model ile ilgili yapılan araştırma literatürünün analiz edilmesi: Çalışmada yer alan tezlerin büyük çoğunluğunda (\%86) aynı kuram veya model kullanılarak yapılmış benzer çalışmaların sonuçlarına yer verilirken; sadece altı çalışmanın (\%14) literatüründe benzer çalışmalara yer verilmediği belirlendi.

- Kavramsal, kuramsal ve deneysel yapının tanımlanması ve araștırmada kullanılması: Çalışmada yer alan doktora tezlerinin \%62,5’inde (n=20) kullanılan 
kuram veya modelin kavram, kuram ve deneysel yapısının belirtilmediği saptanırken; yüksek lisans çalışmalarında bu oran \%63,6 $(\mathrm{n}=7)$ olarak belirlendi.

- Kuram/modelin uygulanabilirliği ve güvenilirliğinin değerlendirilmesi: Çalışmada sadece iki doktora tezinde $(\% 4,7)$ kullanılan kuram veya modelin zayıf yönleri ve uygulamasında yaşanan zorlukların açıklandı̆̆ı saptandı.

\section{Tartışma}

Bu çalışmada 2009-2019 ylları arasında YÖK veri tabanında yer alan, hemşirelik kuram/model kullanılarak yapılan lisansüstü tez çalışmalarının nitelik ve niceliği incelenmiştir.

Literatürde hemşirelik araştırmalarında kuram/model kullanımının sınırlılığına vurgu yapılmakta ${ }^{3,4,7,15}$, son yıllarda ise çalışmalarda hemşirelik kuram ve model kullanımında artış olduğu bildirilmektedir³. Bu araştırmada, literatürle paralel olarak hemşirelik çalışmalarında kuram/model kullanımının düşük düzeyde olduğu $(\% 1,2)$, hemşirelik kuram ve model temel alınarak yapılan araştırmaların da özellikle 2018 yllında (\%37,2; n=16) arttığı saptanmıştır. Kuram/model kullanılarak yapılan araştırmalardaki bu artışın ve hemşirelik uygulamalarına rehberlik etmesinde ve kanıt temelli sağlık bakım hizmeti sunulmasında önemli olduğu düşünülmektedir.

Literatürde hemşirelik kuram/modellerinin karmaşık yapısından dolayı anlaşılmasının ve uygulanabilirliğinin zor olması, hemşirelik eğitimlerinde yeterince üzerinde durulmaması gibi nedenlerin kuram/model kullanımını sinırlandırdı̆̆ bildirilmektedir $3,4,7,16,17$. Göçmen Baykara ve ark. yaptıkları çalışmada $(n=36)$, hemşireler kuram ve modellerin soyut kavramlar olduğunu, anlaşılması ve uygulanmasının zor olduğunu, kuram/model kullanımı konusunda yetkin hemşirelerin sınırlı olduğunu ve kuram/modellerin farklı kültüre uygun olmadığını bildirmişlerdir4. Kaya ve ark.'nın çalışmasında ise hemşirelerin \%93,2'si herhangi bir hemşirelik kuramı/modelini bilmediğini bildirmiştir ${ }^{16}$. Literatürde hemşirelik kuram/modellerinin en fazla uygulandığı çalışmalara bakıldığında, doktora tezlerinin yoğunluğu görülmektedir3,4,13. Literatürle paralel olarak bu çalışmada da, tezlerin \%74,4'ünün $(n=32)$ doktora düzeyinde tasarlandığı saptanmıştır. Hemşirelik kuram ve modellerinin soyut kavramlar olması, anlaşılma ve uygulanmasında yaşanan zorluklar nedeniyle daha çok doktora tezlerinde tercih edildiği kanısındayız. 
Literatürde kullanılan kuram/model araştırmalarının hemşirelik ana bilim dalları ile ilişkisine yönelik bir bilgi yer almazken; çalışmada Halk Sağlığı Hemşireliği (\%27,9), Dahili Hastalıklar Hemşireliği $(\% 20,9)$ ve Doğum ve Kadın Hastalıkları Hemşireliği $(\% 18,6)$ ana bilim dalının ilk sıralarda yer aldığı görülmektedir. Oysaki ana bilim dallarının lisansüstü eğitim içeriklerine bakıldığında Hemşirelik Esasları ana bilim dalına ait eğitimlerde hemşirelik kuram/modellerinin daha fazla yer aldığı görülmektedir. Bu verilere göre, Hemşirelik Esasları ana bilim dalında yapılan lisansüstü tezlerin oranı düşük (\%7) bulunmuştur. Hemşirelik esasları ana bilim dalı başta olmak üzere, hemşirelik alanında yapılan lisansüstü tezlerde hemşirelik kuram ve modellerine daha fazla yer verilmesi gerektiği görüşündeyiz.

Zuhur ve Özpancar'ın yaptıkları araştırmada $(n=56)$, kronik hastalıkların yönetiminde kuram/model uygulanarak yapılan tezler incelenmiştir. İnceleme sonucunda en sık Öz Bakım Eksikliği Kuramı (\%39,3) ve Adaptasyon Modeli’nin (\%17,9) kullanıldığı belirtilmiştiri³. Bu çalışmada ise, sıklıkla Sağlık İnanç Modeli (\%25,o) ve Adaptasyon Modeli’nin (\%22,5) ilk sıralarda yer aldı̆̆ı saptandı. Yapılan çalışmalarda farklı kuram/modellerin kullanım oranları değişmektedir3,4,13. Literatür bilgisine paralel olarak bu durumun, kuram/modellerin uygulanabilirliğine ve uygulandığı örneklem grubuna göre değişkenlik gösterdiği görülmektedir.

Hemşirelik kuram ve modellerinin araştırmalarda kullanımının bilgi birikimini arttırdığı ve mesleki uygulamaları geliştirdiği bilinmektedir,12. Ancak etkili kullanımı açısından değerlendirildiğinde, literatürde kuram/modellerin araştırmalarda kullanımına yönelik bir yöntem veya standardizasyon izlenmesinin önemine vurgu yapılmaktadır3,14. Hemşirelik kuram ve modellerin araştırmalarda nasıl kullanıldığına ve etkilerine yönelik bilimsel çalışmalara ihtiyaç vardır ${ }^{7,18}$. Yapılan incelemede, tezlerin \%90,7'sinde kullanılan kuram/modelin kavramları tanımlanırken, bu kavramların birbiri ile ilişkilerinin açıklandığı belirlenmiştir. Çalışmaların \%86’sında ise, aynı kuram/model kullanılarak yapılmış araştırmalara yer verildiği saptanmıştır. \%9,3’ünde kuram/modele ait birincil kaynağın kullanılmadığı görülmüştür. Şengün İnan ve arkadaşlarının çalışmasında, lisansüstü tez araştırmalarının (n=20) \%50'sinde kuram/modele ait birincil kaynağın kullanılmadığı ve aynı kuram/model kullanılarak yapılmış araştırmalara sınırlı düzeyde (\%35, n=7) yer verildiği bildirilmektedir3. Çalışmada yer alan doktora tezlerinin \%62,5’inde $(\mathrm{n}=20)$ kullanılan kuram veya modelin kavram, 
kuram ve deneysel yapısının belirtilmediği saptanırken; yüksek lisans çalışmalarında bu oran \%63,6 (n=7) olarak belirlenmiştir. Bu verilere göre, değerlendirilen çalışmaların kuram/model kullanımı basamakları doğrultusunda bir yol izlemedikleri söylenebilir.

Araştırma bulgularını sunmak ve kullanılan kuram/modelin uygulanabilirliğini tartışmak, hemşirelik araştırmalarına yön vermek açısından değerlidir. Kullanılan kuram/modelin güçlü ve zayıf yönlerinin açıklanması, uygulanmada yaşanan kolaylık veya zorlukların ifade edilmesi gibi detaylar gelecekte yapılacak çalışmalara rehberlik edecektir3,14. Incelenen araştırmalar içerisinde sadece iki doktora tezinde $(\% 4,7)$ kullanılan kuram/modelin zayıf yönleri ve uygulamasında yaşanan zorluklara yer verilmiştir.

\section{Sonuç ve öneriler}

Sonuç olarak; incelenen çalışmalarda hemşirelik araştırmalarında kuram ve model kullanımının sınırlı olduğu, kuram ve modele dayalı çalışmaların doktorada sıklıkla tercih edildiği, özellikle modele dayalı lisansüstü tez çalışmalarının daha fazla olduğu, kuram ve model kullanımı basamakları doğrultusunda bir yol izlenmediği belirlendi. Bu araştırmaların hemşirelik bilgi birikime olan katkısı göz önüne alındığında, kuram ve model temelli hemşirelik araştırmalarının arttırılması ve kuram/model kullanımına yönelik bir kılavuz oluşturulması önerilmektedir.

\section{KAYNAKLAR}

1. Pektekin Ç. Hemşirelik Felsefesi: Kuramlar-bakım Modelleri ve Politik Yaklaşımlar. 1. Basım. İstanbul: İstanbul Tıp Kitabevi; 2013.

2. Olmaz D, Karakurt P. Hemşirelerin bakım verirken hemşirelik sürecini bilme ve uygulama durumları. DEUHFED. 2019;12(1):3-14.

3. Şengün İnan F, Üstün B, Bademli K. Türkiye'de kuram/modele dayalı hemşirelik araştırmalarının incelenmesi. Anadolu Hemşirelik ve Sağlık Bilimleri Dergisi. 2013;16(2):132-139.

4. Göçmen Baykara Z, Çalışkan N, Öztürk D, Karadă̆ A. Hemşirelikte teori ve model kullanımı: nitel bir çalışma. Çukurova Med J. 2019;44:281-289. 
5. Kaya N, Turan N. Hemşirelik biliminde kavram analizi. Turkiye Klinikleri J Nurs Sci. 2017;9(2):153-163.

6. Türen S, Enç N. A comparison of Gordon's functional health patterns model and standard nursing care in symptomatic heart failure patients: A randomized controlled trial. App Nurs Res. 2020;53:151247. https://doi.org/10.1016/j.apnr.2020.151247.

7. Koç Z, Keskin Kızıltepe S, Çınarlı T, Şener A. Hemşirelik uygulamalarında, araştırmalarında, yönetiminde ve eğitiminde kuramların kullanımı.

Hemşirelikte Eğitim ve Araştırma Dergisi. 2014;14(1):62-72.

8. Fawcett J. Conceptual models and nursing practice: The reciprocal relationship. J Adv Nurs. 1992;17(2):224-228.

9. Peate I. A Systematic approach to nursing care: Models of nursing. Peate I. Learning to care: the nursing associate. Elsevier.2019.

10. Kaya H, Atar NY, Eskimez Z. Hemşirelik Model ve Kuramları. İçinde: Atabek AT, Karadağ A, ed. Hemşirelik Esasları: Hemşirelik Bilimi ve Sanatı. 1. Basım. İstanbul: Akademi basın ve yayıncılık; 2012.

11. Athari SZ, Sharif SM, Nasr AR, Nematbakhsh M. Assessing critical thinking in medical sciences students in two sequential semesters: Does it improve? $J E d u$ Health Promot. 2012;1:30-4.

12. Erdoğan S, Nahcivan N, Esin N. Hemşirelikte Araştırma. 1. Basım. İstanbul: Nobel Tip Kitabevleri; 2014.

13. Zuhur Ş, Özpancar N. Türkiye'de kronik hastalık yönetiminde hemşirelik modellerinin kullanımı: sistematik derleme. HEMAR-G Dergisi. 2017;19(2):5774.

14. Fawcett J, Gigliotti E. Using conceptual models of nursing to guide nursing research: The case of the neuman systems model. Nurs Sci Q. 2011;14(4):339345 .

15. Wu HL, Volker DL. The use of theory in qualitative approaches to research: Application in end-of-life studies. J Adv Nurs. 2009;65(12):2719-2732. 
16. Kaya N, Babadağ K, Yeşiltepe Kaçar G, Uygur E. Hemşirelerin hemşirelik model/ kuramlarını, hemşirelik sürecini ve sınıflama sistemlerini bilme ve uygulama durumları. Maltepe Üniversitesi Hemşirelik Bilim ve Sanatı Dergisi. 2010;3(3):24-33.

17. Üstün B, Gigliotti E. Nursing research in Turkey. Nurs Sci Q. 2009;22(3):206-8.

18. McEwen M, Wills EM. Theoretical Basis For Nursing . 4th edition. Philadeplhia, Lippincott Williams \& Wilkins Wolters Kluwer; 2014.

19. Yüksek Öğretim Kurumu (YÖK) Ulusal Tez Merkezi. https://tez.yok.gov.tr/UlusalTezMerkezi/. Erişim: 04.10.2019. 